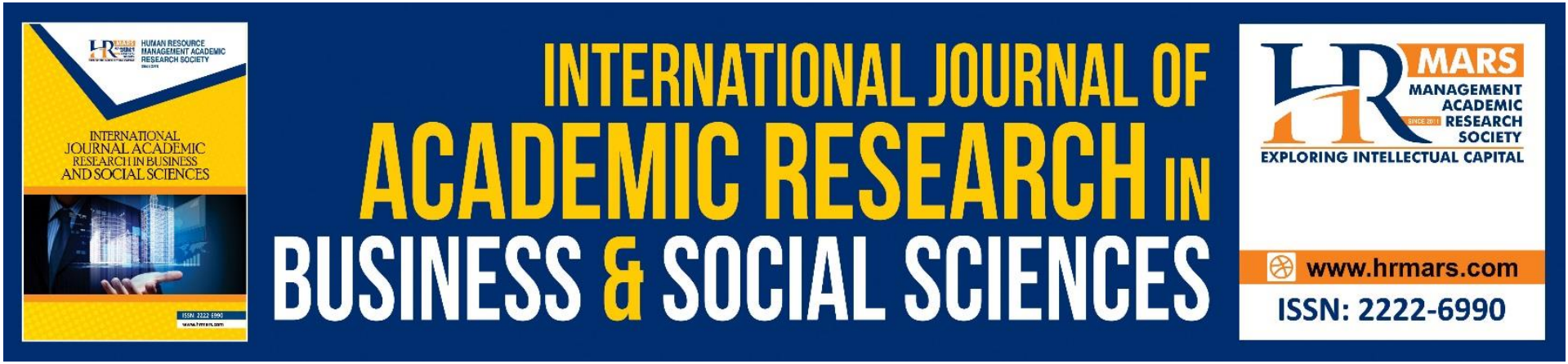

\title{
Adjustment of Polygamous Husbands
}

Muhammad Ajib Abd Razak, Aizan Sofea Amin, Intan Hashimah Mohd Hashim \& Syazwani Drani

To Link this Article: http://dx.doi.org/10.6007/IJARBSS/v11-i6/10220 DOI:10.6007/IJARBSS/v11-i6/10220

Received: 05 April 2021, Revised: 08 May 2021, Accepted: 22 May 2021

Published Online: 13 June 2021

In-Text Citation: (Razak et al., 2021)

To Cite this Article: Razak, M. A. A., Amin, A. S., Hashim, I. H. M., \& Drani, S. (2021). Adjustment of Polygamous Husbands. International Journal of Academic Research in Business and Social Science, 11(6), 891-900.

Copyright: @ 2021 The Author(s)

Published by Human Resource Management Academic Research Society (www.hrmars.com)

This article is published under the Creative Commons Attribution (CC BY 4.0) license. Anyone may reproduce, distribute, translate and create derivative works of this article (for both commercial and non-commercial purposes), subject to full attribution to the original publication and authors. The full terms of this license may be seen at: http://creativecommons.org/licences/by/4.0/legalcode

\section{Vol. 11, No. 6, 2021, Pg. 891- 900}

Full Terms \& Conditions of access and use can be found at http://hrmars.com/index.php/pages/detail/publication-ethics 


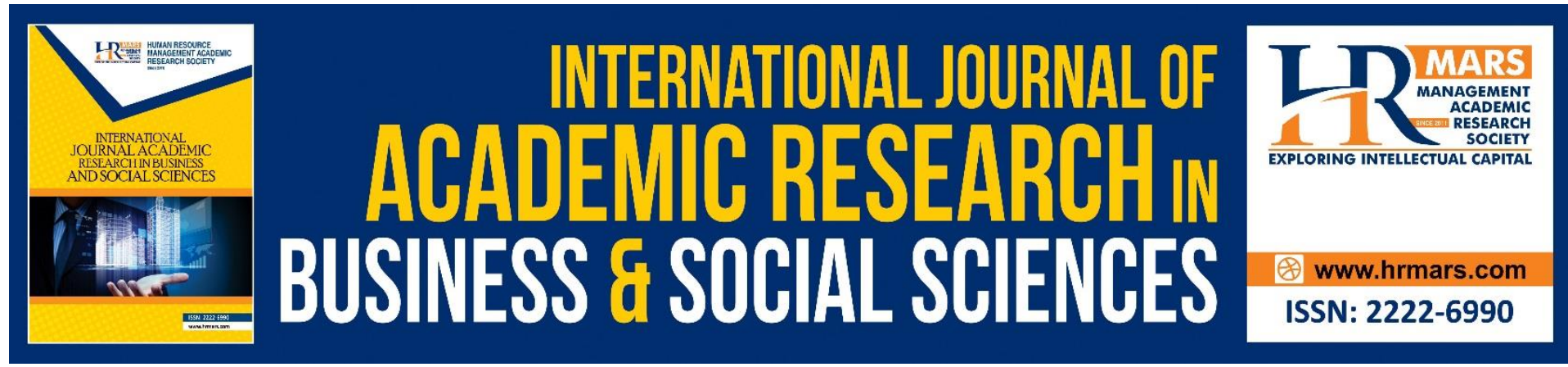

\title{
Adjustment of Polygamous Husbands
}

\section{Muhammad Ajib Abd Razak¹, Aizan Sofea Amin¹, Intan Hashimah Mohd Hashim², \& Syazwani Drani²}

${ }^{1}$ Centre for Research in Psychology and Human Well-being, Faculty of Social Sciences \& Humanities, Universiti Kebangsaan Malaysia, ${ }^{2}$ School of Social Sciences, Universiti Sains Malaysia

Email: aizansofia@ukm.edu.my

\begin{abstract}
The objective of this study was to identify how Malaysian polygamous husbands adapt to polygamous life. A total of six husbands were interviewed. In depth, face-to-face interviews were conducted which were then transcribed and analyzed using thematic analysis. The following four themes emerged: consistently calm and forgiving, streamlined thinking of family members, an adjustment period of one to five years, and increased activities and avoidance of prejudice. The results of this study highlight strategies among husbands struggling to adapt to polygamy harmoniously while also helping their family to adapt to the new family norms. The theme of adaptation is positive in nature and serves as a reference for polygamous men who are struggling with adjustment problems. The conclusions of the study are detailed, and the main implications discussed.
\end{abstract}

Keywords: Adjustment, Polygamy, Husband, Family

\section{Introduction}

Polygamy is a form of marriage recognized and accepted by Islam. This form of marriage is similar to monogamous marriage but differs in terms of responsibilities and laws, involving more onerous commitments (Hamid \& Abdullah, 2019). Epistemologically, polygamy is derived from the Greek, 'poly' or 'polus' meaning many and gamein or gamos meaning marriage (Mukri, 2017). Husbands who enter into a polygamous life encounter difficulty - due to the opposition and disapproval of the existing wife and children, a lack of experience in controlling emotions, failures in time management, financial issues, and problems with managing family conflict, especially at the beginning of a polygamous relationship (Razak, Hashim \& Drani, 2021). While financial factors may affect the harmony of some couples (Zaimah, Abd Hair \& Sarmila, 2016), conflict should be seen from a positive perspective and as a motivator to improve the interaction among a group or an organization (Kiram, Ariffin \& Zakaria, 2017). The issue of a husband's adjustment is critical as they go through a process of transition from a monogamous family to a polygamous one. This presents a great challenge to the husband who serves as head of the family. According to Schneiders' (1960) adjustment theory, self-adaptation is an individual's effort to respond to mental and behavioral challenges as a way of overcoming conflicts and frustrations that occur within oneself in order to achieve harmony with the surrounding environment. There are three aspects that 
influence the adjustment process: motivational factors, attitude to reality, and the basic factors of self-adjustment.

According to Al-Krenawi and Slonim-Nevo (2008), an important element to be studied in a polygamous family is the adaptation, transition and capacity of each member of the family to accept changes in the family structure. Every Muslim monogamous family runs the risk of entering a form of polygamy, and if this does happen they will inevitably face challenges in accepting a polygamous lifestyle (Slonim-Nevo \& Al-Krenawi, 2006). In fact, the transition process affects the adaptation of the new family system in addressing the structure and role of relationships, while responses to situations that arise affect the functional development of family members (Sussman, Steinmertz \& Peterson, 1999). The concept of adaptation can also be extended to the unity of family members who decide to stay or change a marriage or family (Falicov, 1988). The findings of previous studies analyze the adjustment of wives in terms of experiences, coping methods, challenges, acceptance phases, and managing emotions and feelings. As discussed in Subhi, Nasir \& Abd Razak (2020), a first wife's adjustment involves emotional, cognitive and behavioural challenges. Other findings show that married women have difficulty adapting to feelings such as anger, hurt, jealousy, fear, shame, joy, appreciation and affection (Jayos \& Yadzi, 2018). According to Li, Robustelli, and Whisman (2016). Marital adjustment and psychological stress are both significant in the control of neuroses and in how they affect the quality of relations with friends and family. It is important to consider the adaptation process in husbands in order to identify whether the psychological elements applied by husbands have similar relevance among married wives. According to Darmawijaya (2019), polygamous families undergo changes in terms of having to keep the home as a place of physical, social, and psychological resilience, they may face ongoing conflict, and family members have difficulties in socializing with the surrounding community because polygamy has not yet found a place in society. While the adjustments demanded of a husband are not as demanding as those of the married wife, it is necessary to explore these adjustments to determine what is appropriate for the husband. This can also be applied by other polygamous families whose polygamy has had an impact on the existing family structure.

\section{Objective}

To examine the adjustment of polygamous husbands in Malaysia, especially in the Malay Culture. In this study, adaptation and integration are observed based on the changes and transitions that occur when monogamous families begin to transition into polygamous families. The focus is on factors influencing the effective adjustment of husbands.

\section{Method}

This study uses a qualitative research method, consisting of in-depth interviews of six husbands practicing polygamy. The researcher chose the qualitative approach due to the flexible design of the study, as it does not specify what and how the study should be conducted at the beginning (Trochim, 2006). According to Robson (2011), a qualitative study design evolves, develops, and opens up as the study progresses. Objective sampling techniques and snowballs were used in this study. Six husbands were interviewed, all of whom have been polygamous for two to ten years. Informed consent forms were completed by participants. These are intended to ensure legal and ethical safety links are guaranteed between the researcher and the participants (Adams \& Berzonsky, 2006). The form provides a clear table and information on the current study for participants. All the participants agreed 
and gave written consent to participate in the study. All interview sessions were recorded into an audio recorder and then transcribed for data encoding purposes. The recruitment of participants was very difficult, as not all husbands were willing to collaborate and volunteer in the study, given that it involved communicating personal information about their families with the researcher. The data encoding process consisted of three phases, as suggested by Brown and Clarke, to identify issues that arise from the experiences of polygamous families. Table 1.0 below summarizes the demographic profile of the participants in the study.

Table 1.0 Demographic Profile of Participants

\begin{tabular}{lccl}
\hline \multicolumn{1}{c}{ Participant } & $\begin{array}{c}\text { Years of } \\
\text { Polygamy }\end{array}$ & Occupation \\
\hline Ali (not a real name) & 51 & 10 & Businessman \\
Ahmad (not a real name) & 37 & 4 & Businessman \\
Hasan (not a real name) & 52 & 10 & Businessman \\
Zaki (not a real name) & 37 & 2 & Officer \\
Zali (not a real name) & 50 & 17 & Lecturer \\
Hamid (not a real name) & 34 & 7 & Businessman
\end{tabular}

\section{Results and Discussion}

\section{Theme 1: Consistently calm and forgiving}

The theme of being consistently calm and forgiving refers to those participants who have managed to remain calm without worrying about the difficulties of adapting to a life of polygamy. These participants are generally also forgiving of any mistakes or actions that could disrupt the adjustment process within the family.

Ali spoke about how, in adjusting to polygamy, he always maintained an open-hearted, forgiving attitude, making sure he was kind and good to his wives and children. This is because adjustment is a process that goes through many specific phases and it's important to ensure that all family members are pleased with the polygamous approach adopted by the participant. Meanwhile, Ahmad said that adapting to polygamy should involve accepting all its advantages and disadvantages and being able to remain calm in the face of all the tests and turmoil that may occur. In saying this, the participant was aware that polygamy could give rise to issues and problems that may be beyond his control. Furthermore, according to Hasan, adjusting to polygamy in the first phase is a bit uncomfortable because of the time division factor and the feelings this creates within the first and second wives. At the beginning of the polygamous marriage, it was a bit chaotic due to the participant's weakness in understanding the personality and character of the wife. However, after several years of polygamy, the participant managed to adjust by always adopting an open-minded attitude towards his first and second wives through sharing a lot and trying to understand the problems that occur in the household. Below are some sample responses from the participants in the study:

"...In terms of attitude, there must be a lot of open-heartedness, a lot of forgiveness, and kindness towards the wives. There must be the right attitude towards them. The adjustment process involves a lot of trial and error. Sometimes, the husband will not be fair, but as long as he is always improving himself and taking care of himself at the same time ..." (Ali) 
"...Okay, erm, I was in a monogamous marriage for 12 years before I decided to get married again. So I made the decision to enter into polygamy, even though it was not easy. It's not as easy as just asking a woman to get married, no! It took a long time for me, so I'm determined to try fix any crisis that arises in the household, while understanding and accepting the attitudes of my wives and realizing that not everything can please my heart. I need to calm down and forgive any mistakes made and expect the same for me..."(Hamid)

"...Okay, adjustment in the first phase was a little uncomfortable, because it involved dividing my time while still wanting to give a good feeling to my first and second wife, and making sure everything was managed in terms of finance and all that. In this first phase, it was a bit chaotic, but like before, thank God, I learned a lot from it including some very useful knowledge for getting to know my partners ..." (Hamid)

The results of the analysis found that an approach of being open-minded and forgiving is often used by husbands in the process of adapting to a polygamous situation. The study's findings are in line with those of Li, Robustelli, \& Whisman (2016), that is -individuals who are able to control their emotions and cope with unresolved conflicts, who are calm in dealing with problems, and who are self-confident and firm, are able to adapt to the new marriage situation better. In other words, being open-minded and forgiving prevents the husband from becoming excessively emotional. This is crucial as it is very difficult to take care of a woman's heart and feelings if the husband is not open-minded. The researcher sees an open-minded and forgiving approach as a way for the husband to achieve inner calm and prevent small problems or issues from becoming bigger. As noted by Darmawijaya (2019), polygamous families face challenges to their physical, social, and psychological resilience, as well as the potential for ongoing conflict. Clearly, a husband acting in an open-minded and forgiving manner will mitigate the larger threats that can hinder the adjustment process.

\section{Theme 2: Streamlined thinking of family members}

Some of the husbands stated that, in order to rationalize the thoughts of family members, they first needed to provide a clear understanding and information about the problems and difficulties that can arise while the process of adaptation to a polygamous family environment is underway. The rationalizing of thoughts involved both the participants and family members. According to Ali, Ahmad and Hasan, the process of rationalizing the thoughts of wives and children is necessary so that family members can fit into the polygamous pattern of life. The process of rationalization involves asking a series of questions such as, why was polygamy created? why live in the same house? why marry another? why live as a polygamous family? These questions are always discussed with the wife concerned to ensure that the husband and wife can adapt, unite as one family, and live in comfort. Rationalizing the thoughts of the wife and children ensures an understanding of the true purpose and goal of polygamy. The responses from Ali, Ahmad and Hasan in this context are quoted below; "...Before entering into polygamy, there was a process of rationalizing my wife's thoughts. Why do you want to practice polygamy? - it's like two brothers living in the same house when they have a house next door to each other with a wall in between. But, if we can't get a house like that, we stay in the same house, with a happy wife and children, the brother can do his own things and there is no need to take turns..."(Ali).

"...you need to adjust yourself to an increased sense of responsibility. When I think back about the house, school for children, food and drink, clothes, protection, health and other things for 
this family, I have to make sure I'm strong. I can't rely on one source of income alone, so I need to get my family members to understand about the real situation..." (Ahmad)

"...In my previous life, even though I was married, I was less focused on issues. But after I entered into a polygamous situation, my responsibilities and the burden I have to bear became greater - especially in terms of expenses and finances. So I'm more focused on work, looking for income, and I'm more insightful, knowing things twice as much as before...My wives have seen the change and I have explained it a lot to them..."(Hasan)

The results of the study found that in general, the husband needs to rationalize the thinking of his wives and children to launch the process of adaptation to polygamy in the family. These findings support a study conducted by Utami \& Mawarpury (2019) which found that the main challenge for women and men in adapting to polygamy is managing conflict. As such, the husband seeks to rationalize his wives and children's thoughts to avoid or reduce frequent conflicts in the family. Schneiders'(1960) theory of self-adjustment states that one of the aspects of effective self-adjustment by an individual is rational judgment and the ability to direct oneself. When an individual is rational, then the changes that take place in their environment can be adapted to well and effectively. This statement also reinforces the findings of the study of Subhi, Mohd Nasir, \& Abd Razak (2020), that family members find it difficult to survive in a polygamous life because they have cognitive weaknesses while managing conflict.

\section{Theme 3: Adjustment period of one to five years}

The results of the study indicate that most husbands take between one to five years for the adjustment process. This was the time period required by the participants to be able to adequately conform to polygamous living standards. According to Ahmad, who has four wives, the process of adaptation and unifying took a year for each wife. One year was seemingly sufficient for the participant to feel comfortable with the polygamous arrangements, based on the established vision and mission. Hasan also said that the time needed to adapt was 1 to 2 years, long enough for the polygamy process to become calm and acceptable to the first wife while ensuring that the first and second wives were able to build a good relationship with each other. Meanwhile, Hamid began to adapt when the polygamous marriage was in the second phase of 5 years, when his wives and children began to recite and understand the Quran, as well as attend religious lectures and remembrance programs, in order to become more compassionate and strive for harmony. Below are a few interview quotes from some of the participants on this matter:

"...each person took a year. The most obvious change was in terms of time, because we don't have much time to socialize with friends and have chit-chat. Some other men who are polygamous, but still spend lots of time with friends, their household suffers - the children are disrespectful, relationships with children are ruined. In fact, this is what give polygamy a bad name..."(Ahmad)

"...In a year or two, it feels like when you look at your first wife, you can accept the situation and things become calm again..."(Hasan)

"...It feels like the first phase, the first 5 years, is a time for exploration. What kind of partner are you, what kind of couple are you, how do you want to manage, how do you want to do 
this, how do you want to understand his weaknesses? Then I had to take this wife to recite the Al-Quran - the children too - listen to lectures. We took them to the dhikr program..." (Hamid)

The results of the study revealed that, on average, the husbands in this study took from one to five years to adapt to polygamous life. Regarding the adjustment period, the findings of this study expand those of the study of Sandu and Salceanu (2020) who state that the older a couple are when they get married, the higher their level of relationship satisfaction. According to Sandu and Salceanu (2020), the level of conflict is generally high at the beginning of a marriage because it is difficult to adapt to the new family structure. A couples' satisfaction with their marriage will only increase during the adjustment process after successfully resolving various problems which occur during the adjustment period. Although there is no specific study on the period of adjustment in polygamous marriage, the results of this study complement those from the study by Al-Krenawi \& Kanat-Maymon (2017) who affirmed that an adjustment period is essential to stabilize polygamous life, because each family must adapt to ongoing changes such as the husband's treatment of his wives and children, economic management, marital satisfaction and family functionality.

\section{Theme 4: Increased activities and avoidance of prejudice}

The theme of increased activities and avoidance of prejudice refers to the fact that the participants need to plan various activities to strengthen relationships and close gaps within their family, as well as to correct the perceptions and prejudices of their wives with regards to their efforts to harmonize their polygamous household. According to Ali, Ahmad and Zaki, an increase in family activities and an avoidance of prejudice were ways for them to adapt to and manage their polygamous lives well. The participants also played a role in correcting perceptions, while encouraging family members to experience, not to fear making mistakes, accept the negative thoughts of others, read a lot and do other family activities, thereby enabling the participants to adjust their relationships with their first and second wives and children holistically. Suitable family activities included weekly usrah/halaqah, deliberations, waterfall bathing, fishing together, involving the family in associative activities, and selfreflection. Below are some interview quotes from the three above-mentioned participants on this matter:

"...Do a lot of activities, avoid prejudice, the husband has to play a role in correcting perceptions and has to be brave in trying. It doesn't matter if it's wrong, it doesn't matter if it turns out badly - don't be afraid, just do it..."(Ali)

"...As a way of bonding, do some things together. God wants to help with all sorts of things, including improving the marriage. Take your wives on a picnic together, gather them in a ceremony, and if possible ensure there is no separation in the family's social activities - they must be combined..."(Ahmad)

"...I often take my wife and sweetheart and children to the park, so that they can become close and adapt to each other. I know I can't be perfect for people, I'm not a prophet. However, I try to do good and to be very patient..."(Zaki)

The results of the study found that the husbands took the approach of increasing activities and avoiding prejudice in order to adapt to polygamous life. The findings of the study support the statement of the researchers Zaitoun \& Hasan (2017) that during the phase of adjustment 
from monogamy to polygamy, children will experience significant changes in terms of selfconfidence and intellect. Similarly, the study supports the findings of Anita (2015), who stated that through friendly and harmonious relationships, as well as gender cooperation between couples, well-being in the family can be achieved. The findings of this study also support those of previous studies in that an increase in activities and avoidance of prejudice is one of the husband's methods to strengthen the relationships between all family members. With these extra activities, the children's self-confidence will be enhanced, which in turn makes it easier for them to be friendly with their stepmothers and step-siblings. These activities can create positive social interactions and build healthy emotions between family members, and lead to friendlier relations between husbands and wives. According to the husbands in this study, increased family activities include things such as usrah (weekly halaqah, discussions with the whole family, deliberations), picnics, waterfall bathing, fishing together, and involving the family in associative activities. In addition, taking the first and second wife's families to the park to chat and share in a heart-to-heart and relaxed manner is a good way of correcting the perceptions and prejudices of the wives about their husband's plans and intentions - and helps to manage the polygamous situation.

\section{Conclusion}

In general, this study presents four key themes in identifying the forms of adjustment to a polygamous family from the point of view of the husbands. These are - consistently calm and forgiving, streamlined thinking of family members, an adjustment period of one to five years, and increased activities and avoidance of prejudice. Adaptation or adjustment, in the context of this study, refers to the ability of family members to cope with changes in the relationship role structure, along with their ability to respond to situations and developments that stress the functioning of family members (Sussman, Steinmertz \& Peterson, 1999). The findings support those in previous studies with regard to the experiences of family members in accepting and adjusting to polygamous life. As revealed by Subhi, Nasir \& Abd Razak (2020), full acceptance of polygamous life takes time. Although previous studies have not determined a specific time period needed to adapt to polygamy, this study has contributed new findings by elaborating more specifically the time periods required to adapt, especially by husbands. According to Boerner et al., (2014), the behavior of the husband, his manner of treatment, and the role of power and attitude are factors that contribute to the adjustment process in the family. Meanwhile, according to Yerges et al., (2017), polygamous women are often dissatisfied with polygamous married life, have despairing thoughts, and need to express their hearts and feelings every day to continue living life in polygamy. This is because polygamous women often think negatively and feel themselves to be treated unfairly and not understood by their husbands.

So, to ensure that family members can adapt well, the participants spoke of the need to rationalize the thoughts of their wives and children. This includes explaining their actions towards family members as well as raising questions about the true purpose of polygamy, so this can be understood by the family members. An appropriate time period is required for husbands to coordinate and organize polygamous life as stated in a study by Al-Krenawi, Slonim-Nevo and Graham (2006), especially given that polygamous men have less marital satisfaction than monogamous men, due to difficulties in managing conflict and jealousy among wives, as well as the burden of having to improve relationships between each family member. The participants in this study stated that, during the adjustment period, several 
things need to be managed well, such as building and repairing relationships between first and second wives, organizing polygamy based on a set vision and mission, exploring and understanding their wives in terms of character, attitude and behavior, educating their wives and children to understand religion, implementing zikir programs for the purpose of kindness and mujahadah, as well as understanding the weaknesses of their wives in order to treat them accordingly. While all members of the family have to undergo an adjustment process, the findings of this study provide a more comprehensive and deeper understanding of the forms of adjustment among polygamous husbands in Malaysia. The results of the study are also consistent with relevant theories, in particular the theory of personal adjustment by Schneider (1960). The study successfully contributes to the body of knowledge, especially in the field of family counseling, by increasing our understanding of the implications of adaptation to polygamy in an integral manner. Ethical approval was granted by the Human Research Ethics Committee, University of Science, Malaysia (Ref USM/JEPem/18070324). Participants consented to anonymized quotes being used in dissemination.

\section{References}

Adams, G. R., \& Berzonsky, D. M. (2006). Blackwell handbook of adolescence. United Kingdom: Blackwell Publishing Ltd.

Al-Krenawi, A., \& Kanat-Maymon, Y. (2017). Psychological symptomatology, self-esteem, and life satisfactions of women from polygamous and monogamous marriages in Syria. International Social Work, 60(1), 196-207.

Al-Krenawi, A., \& Slonim-Nevo, V. (2008). Psychosocial and familial functioning of children from polygynous and monogamous families. The Journal of social psychology, 148(6), 746-764.

Anita, R. (2015). Harmoni dalam keluarga perempuan karir: upaya mewujudkan kesetaraan dan keadilan gender dalam keluarga. PALASTREN, 8(1), 1-34.

Al-Krenawi, A, Slonim-Nevo, V., \& Graham, J. R. (2006). Polygyny and its impact on the psychosocial well-being of husbands. Journal of Comparative Family Studies, 37(2), 174-189.

Boerner, K., Jopp, D. S., Carr, D., Sosinsky, L., \& Kim, S. K. (2014). His and her marriage? The role of positive and negative marital characteristics in global marital satisfaction among older adults. Journals of Gerontology, 69(4), 579-589.

Dharmawijaya, A. (2019). Dampak poligami siri terhadap kehidupan keluarga di Desa Cigugur Girang Bandung Barat. Asy-Syari'ah, 21(2), 207-220.

Falicov, J. C. (1988). Family Transitions: Continuity and change over the life cycle. New York: The Guilford Press.

Hamid, R., \& Abdullah, S. (2019). Merisik fakta poligami. Sintok: UUM Press.

Kiram, M. N., Ariffin, R. M., \& Zakaria, J. (2017). Conflict Management Styles and Its Impact on Family Institution in Novel Saga. Akademika, 87(2), 77-87.

Mukri, M. (2017). Poligami: Antara teks dan konteks sosial. Jurnal Al-Adalah, 14(1), 201-224.

Razak, M. A. A., Hashim, I. H. M., \& Drani, S. (2021). Patterns of Relationships in Polygamous Families in Malaysia. International Journal of Academic Research in Business and Social Sciences, 11(3), 7-18.

Robson, C. (2011). Real world research: A resource for users of social research methods in applied settings. United Kingdom: Wiley Chichester.

Schneiders, A. A. (1960). Personal adjustment and mental health. New York: Holt, Reinhart, and Winston Inc. 
Slonim-Nevo, V., \& Al-Krenawi, A. (2006). Success and failure among polygamous families: The experience of wives, husbands, and children. Family Process, 45(3), 311-330.

Sandu, L. M., \& Salceanu, C. (2020). Psychosocial factors that influence marital couple duration. Technium Social Sciences Journal, 5, 151-160.

Sussman, B. M., Steinmertz, S. K., \& Peterson, W. G. (1999). Handbook of marriage and the family. New York: Plenum Press.

Subhi, N., Nasir, M. N. H., \& Abd Razak. M. A. (2020). Poligami: Pengalaman dari Perspektif Isteri Pertama. Jurnal Psikologi Malaysia, 34(3), 200-213.

Jayos, S., \& Yadzi, M. N. A. (2018). Perkongsian cabaran perasaan dan pemikiran klien wanita hidup bersama suami yang berpoligami. Jurnal at-taujih bimbingan dan kaunseling Islam, 1(1), 32-49

Li, A., Robustelli, B. L, \& Whisman, M. A. (2016). Marital adjustment and psychological distress in Japan. Journal of Social and Personal Relationships, 33(7), 855-866.

Trochim, W. (2006). The research methods knowledge base (2th ed). Retrieved from httapi://www.socialresearchmethods.net/kb.

Utami, T. R., \& Mawarpury, M. (2019). Manajemen konflik keluarga poligami dan monogami rini. International Journal and Gender Studies, 5(2), 47-54.

Yerges, A. L., Stevensa, P. E., Valhuma, M. L., Bauera, W., Mwenyekondeb, T. N., Weinhardtc, L. S., Galvao, W. L. (2017). Women's narratives of living in polygamous marriages: Rural Malawian experience distilled and preserved in poetic constructions. Health care for women international, 38(8), 873-891

Zaimah R., Abd Hair, A., \& Sarmila M.S. (2016). Determinant Factors of Financial Well-being of Workers in Malaysia. Journal of Social Sciences \& Humanities, 1, 229-240.

Zaitoun, Z., \& Lujain, H. (2017). Polygamy and its impact on academic achievement and selfconfidence among a sample from Sattam bin Abdul Aziz University students. Journal of the College of Education for Women, 28(1), 58-70. 